\title{
FK506 Requires Stimulation of the Extracellular Signal-Regulated Kinase 1/2 and the Steroid Receptor Chaperone Protein p23 for Neurite Elongation
}

\author{
Bruce G. Gold ${ }^{a, b}$ Yong-Ping Zhong ${ }^{a}$ \\ ${ }^{a}$ Center for Research on Occupational and Environmental Toxicology, and bepartment of Cell and \\ Developmental Biology, Oregon Health and Science University, Portland, Oreg., USA
}

\author{
Key Words \\ Chaperone proteins - Extracellular signal-regulated \\ kinase · FK506 - Immunophilin - Mitogen-activated \\ protein kinase $\cdot$ Nerve regeneration $\cdot$ Steroid hormone \\ receptor
}

\begin{abstract}
The immunosuppressant drug FK506 (tacrolimus) accelerates nerve regeneration in vivo and increases neurite elongation in vitro. We have proposed that the mechanism involves binding to the FK506-binding protein 52, a chaperone component of mature steroid receptor complexes, and a subsequent 'gain-of-function' involving p23 dissociation from Hsp-90 in the complex and extracellular signal-regulated kinase (ERK) activation. Here, we tested the involvement of the ERK and p23 in neurite elongation by FK506 in human SH-SY5Y cells. FK506 $(10 \mathrm{nM})$ increased ERK1/2 phosphorylation at 12 and $24 \mathrm{~h}$, eliciting a 3.5 -fold increase at $24 \mathrm{~h}$, which was inhibited in a concentration-dependent manner by an antibody (JJ3) to recombinant human p23. Neurite elongation by FK506 (10 nM), determined by measuring neurite lengths at 96 and 168 h, was completely blocked by the mitogen-activated protein kinase inhibitor PD 098059 $(10 \mu M)$ and prevented, in a concentration-dependent fashion, by the p23 antibody. Taken together, the results demonstrate the functional role for ERK and p23 in the
\end{abstract}

neurite elongation activity of FK506 and reveal a novel signal transduction pathway involving p23 activation of ERK. We suggest that compounds that stimulate or mimic p23 may be useful for accelerating nerve regeneration.

Copyright $@ 2004$ S. Karger AG, Basel

\section{Introduction}

FK506 (tacrolimus) is an immunosuppressant drug widely used to prevent rejection of organs [29, 50, 51] and tissue, including nerve and hand grafts [10, 32, 37]. The drug also accelerates nerve regeneration in animals [24, $25,36,58]$ and in human hand transplantations $[10,32$; for a review, see ref. 18]. While immunosuppression is dependent on both calcineurin inhibition and binding to the FK506-binding protein 12 (FKBP-12) [for reviews, see ref. 13, 49], the findings that nonimmunosuppressant derivatives of FK506 that do not inhibit calcineurin nor bind to FKBP-12 retain the neurotrophic activity [7, 20, $27,52,53$ ] reveal that the mechanism eliciting an increase in nerve regeneration is distinct from that underlying immunosuppression. In contrast, our studies [14, 17, 23, 26] indicate an involvement of FKBP-52, a chaperone/ heat shock protein that comprises mature steroid receptor complexes [39, 42, 54].

\section{KARGER \\ Fax +41613061234 \\ E-Mail karger@karger.ch \\ www. karger.com

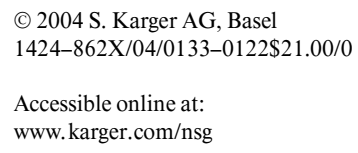

Bruce G. Gold, Center for Research on Occupational and Environmental Toxicology and Department of Cell and Developmental Biology

Oregon Health and Science University, 3181 S.W. Sam Jackson Park Road

Portland, OR 97201-3098 (USA)

Tel. +1 503494 2505, Fax +1 503494 6831, E-Mail gold@ohsu.edu 
The mature steroid receptor complex consists of the steroid hormone-binding receptor and three chaperone components: an immunophilin (FKBP-52, FKBP-51 or cyclophilin 40), Hsp-90 and p23 [6, 31]. FKBP-52 is bound to Hsp-90 via their tetratricopeptide repeat domains [6], and Hsp-90, which binds directly to the steroid hormone-binding receptor, also binds p23 [47]; FKBP-52 appears to also bind to the steroid hormone-binding component [47]. The only known function for $\mathrm{p} 23$ is that its binding to Hsp-90 is essential for maintaining the steroid hormone-binding component in a conformation enabling high-affinity binding for the ligand $[8,9,11]$. Upon ligand binding, the chaperone proteins dissociate from the complex, enabling the steroid hormone-binding component to bind to steroid response elements and, thereby, activating transcription. Hsp-90 binding compounds (i.e., geldanamycin and radicicol) also prevent p23 from binding to Hsp-90 [41], but reduce transcriptional activation [43].

Based on the similar neurite elongating activities of geldanamycin [23] and radicicol [16, 19,44], we proposed that dissociation of p23 from Hsp-90 in the mature steroid receptor complex (rather than classical activation of steroid response elements) is the key event in the ability of these different classes of compounds to increase neurite elongation/nerve regeneration [17, 23, 26]. Furthermore, following its dissociation from the steroid receptor complex [17, 26], Hsp-90 may activate the mitogen-activated protein kinase pathway through its known interaction with Raf and the mitogen-activated protein kinase kinase (MEK) [40, 45], a signal transduction pathway known to be involved in neurite outgrowth [48]. Whether p23 is also able to activate the mitogen-activated protein kinase pathway remains unexplored.

Thus, in the present study, we examined the roles of extracellular signal-regulated kinase (ERK) and p23 in mediating the ability of FK506 to increase neurite elongation in human neuroblastoma SH-SY5Y cells. Preliminary reports of a portion of this work have been presented $[15,16,19-22]$.

\section{Materials and Methods}

\section{SH-SY5Y Human Neuroblastoma Cells}

SH-SY5Y human neuroblastoma cells were maintained in Dulbecco's modified Eagle's medium (F12; Gibco) supplemented with $15 \%$ fetal calf serum (Hyclone), $50 \mathrm{IU} / \mathrm{ml}$ of penicillin and $50 \mathrm{mg} / \mathrm{ml}$ streptomycin (Gibco) at $37^{\circ} \mathrm{C}$ with $5 \% \mathrm{CO}_{2}$. Cells were plated in six-well plates (Falcon) at 15,000 cells/well and treated with $0.4 \mu M$ aphidicolin (DNA polymerase inhibitor; Sigma). At 5 days, cells were washed, treated with nerve growth factor (NGF; $10 \mathrm{ng} / \mathrm{ml}$ ), to induce process outgrowth, in the presence or absence of FK506 (10 nM). PD
$098059(10 \mu M)$ was added along with the NGF and FK506 for Western blot studies or $48 \mathrm{~h}$ later for neurite elongation studies. For p23 antibody studies, the cells (as above) were permeabilized by cotreatment with saponin $(15 \mu \mathrm{g} / \mathrm{ml})$ for $10 \mathrm{~min}$ in the presence of an IgG1 antibody (JJ3) to recombinant human p23 (Affinity BioReagents, Inc.) at $200-1,600 \mathrm{ng} / \mathrm{ml}$, and (after $10 \mathrm{~min}$ ) replaced with fresh medium without saponin but with the JJ3 antibody. All treatments were run in duplicate and the experiments repeated twice.

\section{Western Blots}

SH-SY5Y cells were collected at 12 and $24 \mathrm{~h}$ following treatment. To reduce ERK phosphorylation to baseline levels, fetal calf serum was not added during the last $12 \mathrm{~h}$ of treatment. Following treatment, the cells were washed twice with ice-cold phosphate-buffered saline, sonicated for $15 \mathrm{~s}$ on ice, and then heated at $100^{\circ} \mathrm{C}$ for $5 \mathrm{~min}$. Protein concentrations in each sample were determined using the Bradford dye-binding procedure (BioRad, Richmond, Calif., USA). Equal amounts of protein $(20 \mu \mathrm{g})$ were applied to a $10 \%$ SDS-PAGE gel and the proteins transferred to a nitrocellulose membrane. The blotted membranes were pretreated with Tris-buffered saline containing 5\% nonfat milk and $0.1 \%$ Tween-20 for $1 \mathrm{~h}$ at room temperature, followed by a primary antibody specific to phospho-ERK (Santa Cruz Biotechnology, Inc., Santa Cruz, Calif., USA) or to total ERK (Promega, Madison, Wisc., USA) at 1:1,000 overnight at $4{ }^{\circ} \mathrm{C}$, and visualized by horseradish peroxidase-conjugated goat antirabbit or goat antimouse secondary antibody $(1: 1,000)$ for $1 \mathrm{~h}$ at room temperature. Peroxidase activity was detected using the enhanced chemiluminescence light-based detection system and the signal intensity was determined using a GS-363 phosphorimager and Molecular Analysis software (BioRad). Values were expressed as pixel density units.

\section{Neurite Elongation Measurements}

For analysis of process length, cells (20 fields per well) were randomly photographed at 96 and $168 \mathrm{~h}$. Neurite lengths were measured on photographic prints (final magnification $\times 360$ ) using a SummaSketch III (Summa graphics) digitizing tablet and Bioquant Classic 95 software (R\&M Biometrics, Nashville, Tenn., USA); only those processes greater than twice the cell body length were measured. For the p23 dose-dependency study, the $1,200 \mathrm{ng} / \mathrm{ml}$ and $1,600 \mathrm{ng} / \mathrm{ml}$ data (which were obtained from a separate experiment) were normalized to the FK506 level in that experiment and these values are presented with the other data shown in figure $3 \mathrm{a}$.

\section{Statistical Analysis}

Values from duplicate wells were not significantly different from each other and the values for each treatment groups were combined. Mean values were compared using a one-way analysis of variance followed by Newman-Keuls multiple comparison test for comparison of individual values (WINKS 4.62, TexaSoft, Cedar Hill, Tex., USA). Values are mean \pm SEM.

\section{Results}

\section{FK506 Increases ERK1/2 Phosphorylation}

We examined whether FK506, at a concentration that maximally stimulates neurite outgrowth in human SHSY5Y cells [23], increases ERK phosphorylation. In pre- 


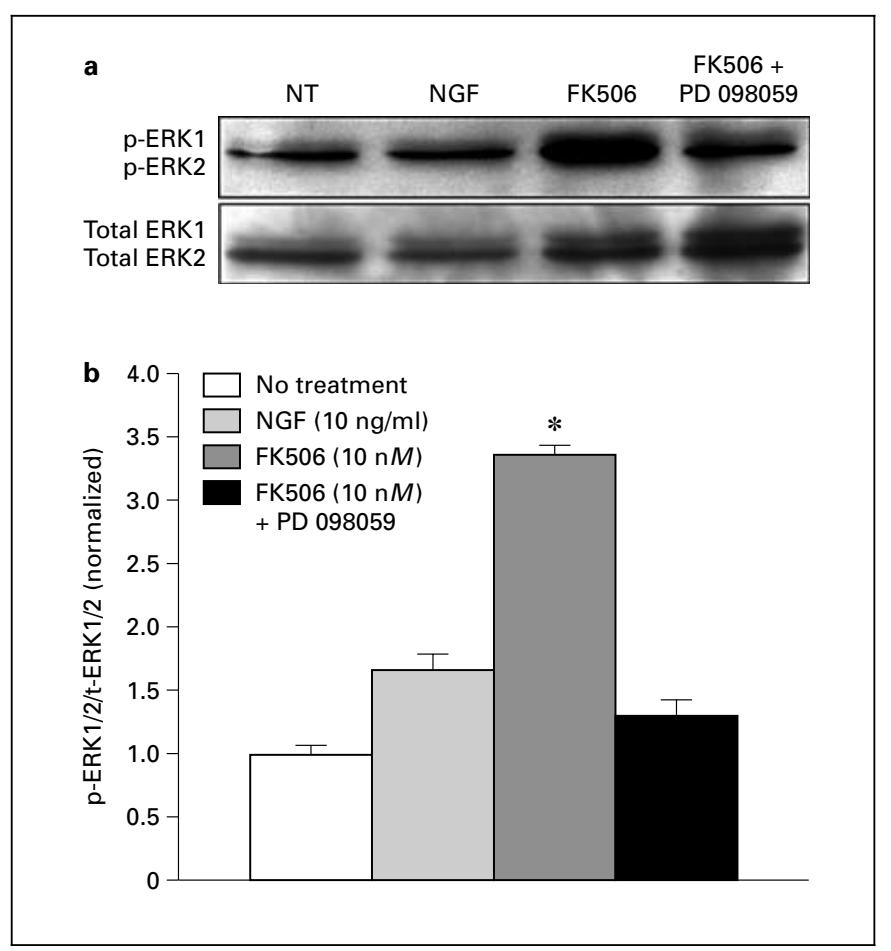

Fig. 1. FK506 increases ERK phosphorylation (activation). a Representative Western blots showing phosphorylated ERK1 and ERK2 (p-ERK1 and p-ERK2) and total ERK levels at $24 \mathrm{~h}$ after no treatment (NT) or treatment with NGF only, NGF + FK506, or NGF + FK506 and the MEK inhibitor PD 098059. FK506 (10 nM), in the absence of serum, increases phosphorylated ERK (primarily ERK2 at $24 \mathrm{~h}$ ) levels specifically (total ERK is unaltered) compared with NGF alone, which is prevented by PD 098059. Equal amounts of protein $(20 \mu \mathrm{g})$ were applied to each lane. b Mean values (averaged from three experiments) showing relative increase in signal intensity for the bands at $24 \mathrm{~h}$, expressed as a percentage of no treatment (no serum, no NGF) control values. Signal intensity was detected using a GS-363 phosphorimager and Molecular Analysis software (see Materials and Methods). t-ERK $=$ Total ERK. ${ }^{*} \mathrm{p}<0.05$, compared with other treatment groups.

liminary studies, we found that serum alone produced a marked increase in phosphorylated ERK levels, obscuring any effect of FK506 (data not shown). Since serum alone activates ERK [5, 35, 56], cells were starved for $12 \mathrm{~h}$ to reduce phosphorylated ERK to baseline levels.

In the absence of serum (for $12 \mathrm{~h}$ ) and in the presence of NGF (10 ng/ml), FK506 (10 nM) increased ERK phosphorylation at 12 (not shown) and $24 \mathrm{~h}$ (fig. 1a). Interestingly, there appeared to be a differential effect with time, as ERK1 showed greater levels of phosphorylation at $12 \mathrm{~h}$, whereas ERK2 phosphorylation was selectively increased at $24 \mathrm{~h}$. ERK phosphorylation was prevented by cotreat- ment with the MEK inhibitor, PD 098059 (fig. 1a). Quantitation of the Western blots revealed that FK506 significantly increased ERK phosphorylation at $24 \mathrm{~h}$ by over 3fold, which was inhibited by PD 098059 (fig. 1b). In contrast, FK506 did not stimulate ERK in the absence of NGF (data not shown), consistent with its lack of effect on neurite outgrowth in the absence of NGF [23]. It was not possible to examine time points longer than $24 \mathrm{~h}$ since ERK phosphorylation was too high in the presence of serum for more than $12 \mathrm{~h}$ (i.e., half of the 24-hour period) and the cell died when we attempted to examine time points greater than $24 \mathrm{~h}$ by increasing the serum deprivation beyond $12 \mathrm{~h}$.

\section{Neurite Elongation by FK506 Is Functionally \\ Dependent upon ERK Stimulation}

We next asked whether ERK stimulation is functionally required for FK506 to increase neurite elongation in human SH-SY5Y cells. Since NGF stimulates ERK (fig. 1), which is required for the initial stages of the activity of NGF [57, 59], we were concerned that inhibition of ERK would impair the action of NGF, secondarily inhibiting the activity of FK506. As opposed to the Western blot studies (see above), this issue arose since longer periods of exposure (96-168 h) are needed to assess neurite elongation [23].

To ensure that we were studying the dependence of FK506 on ERK and not merely its dependence on NGF, we first developed a protocol whereby PD 098059 would not inhibit the neurite outgrowth activity of NGF. We found that PD 098059 did not inhibit neurite elongation at $96 \mathrm{~h}$ (data not shown) and $168 \mathrm{~h}$ (fig. 2) when given $48 \mathrm{~h}$ after NGF treatment. In contrast, PD 098059, when added $48 \mathrm{~h}$ after addition of FK506 and NGF, completely prevented the ability of FK506 to stimulate neurite elongation, reducing mean neurite lengths to those observed with NGF alone (fig. 2); the PD 098059 compound also prevented neurite elongation by several nonimmunosuppressant FK506 derivatives (data not shown), demonstrating that the requirement for ERK activation is, like nerve regeneration, independent of calcineurin inhibition $[27,52,53]$.

\section{Neurite Elongation by FK506 Is Functionally \\ Dependent upon $\mathrm{p} 23$}

p23 is an essential component of mature steroid receptor complexes, being necessary for maximal binding affinity of the steroid ligand $[9,11]$. Our working hypothesis $[20,23]$ is that neurite elongation/nerve regeneration by steroid hormones, neuroimmunophilin ligands (e.g. 


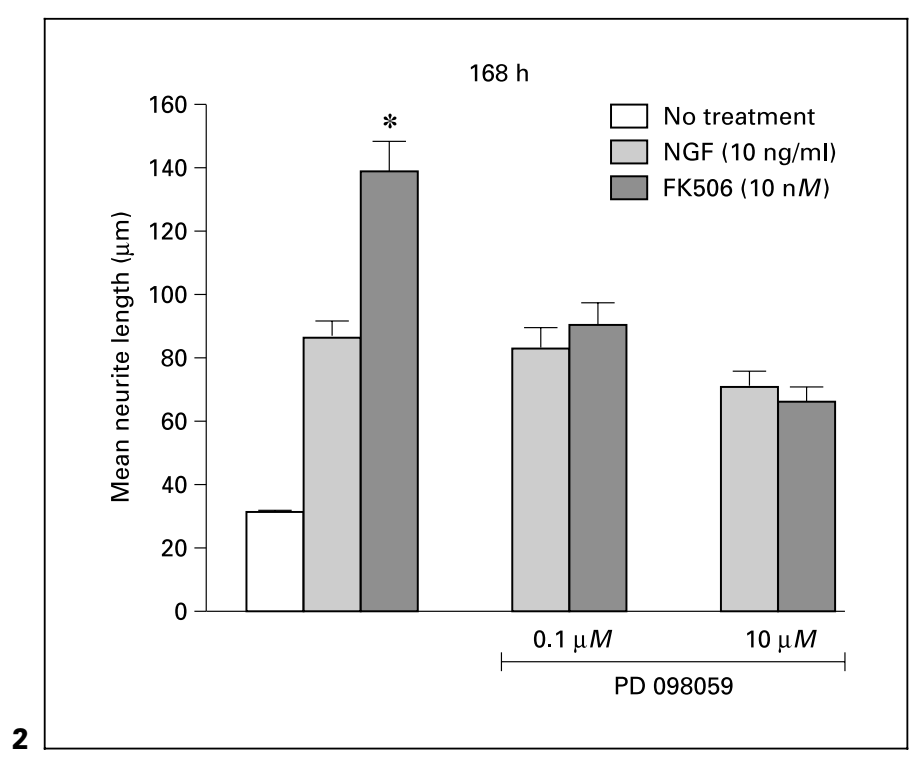

Fig. 2. The MEK inhibitor PD 098059 inhibits neurite elongation by FK506. Mean neurite lengths in SH-SY5Y cells at $168 \mathrm{~h}$ shown for no treatment, and NGF only and NGF + FK506 in the presence or absence of PD 098059 at two concentrations. The MEK inhibitor completely inhibits the neurite outgrowth activity of FK506 (reducing it to NGF only levels), being somewhat (albeit not significantly) more effective at the higher concentration $(10$ vs. $0.1 \mu M)$. In contrast, the PD 098059 compound, added $48 \mathrm{~h}$ after NGF, does not inhibit the activity of NGF alone. Similar results were obtained in two replicate experiments. ${ }^{*} \mathrm{p}<0.05$, compared with NGF only.

Fig. 3. A p 23 antibody (JJ3) inhibits neurite elongation by FK506. a Mean neurite lengths in SH-SY5Y cells at $168 \mathrm{~h}$ shown for no treatment, and NGF only, and NGF + FK506 in the presence or absence of the p23 antibody at 5 concentrations $(200,400,800,1,200$ and $1,600 \mathrm{ng} / \mathrm{ml}$ ). At $800 \mathrm{ng} / \mathrm{ml}$, the p23 antibody completely inhibits the neurite outgrowth activity of FK506 (reducing it to NGF only levels). At higher concentrations $(1,200$ and $1,600 \mathrm{ng} / \mathrm{ml})$, the antibody is even more effective, reducing neurite outgrowth below NGF only levels. For antibody penetration, the cells were permeabilized by cotreatment with saponin $(15 \mu \mathrm{g} / \mathrm{ml})$ for $10 \mathrm{~min}$. Similar results were obtained in two replicate experiments. ${ }^{a} \mathrm{p}<0.05$, compared with NGF only and all p23 antibody-treated groups; ${ }^{\mathrm{b}} \mathrm{p}<0.05$, compared with p23 antibody at $200 \mathrm{ng} / \mathrm{ml} .{ }^{c} \mathrm{p}<0.05$, compared with p23 antibody at 200, 400 and $800 \mathrm{ng} / \mathrm{ml}$ and NGF only. Inset: controls showing lack of effect of saponin treatment on NGF-induced neurite elongation (compare NGF and NGF + saponin) and failure of a mouse IgG antibody to alter NGF-induced (left) and FK506-induced (right) neurite elongation. b Light micrographs showing representative SHSY5Y cells treated with NGF + FK506 in the absence (top) or presence (bottom) of the p23 antibody. Note that the processes from cells treated with the p23 antibody $(800 \mathrm{ng} / \mathrm{ml})$ appear shorter in length and appear jagged and more beaded (arrowheads) compared with those not treated with the antibody. Magnification $\times 120$.
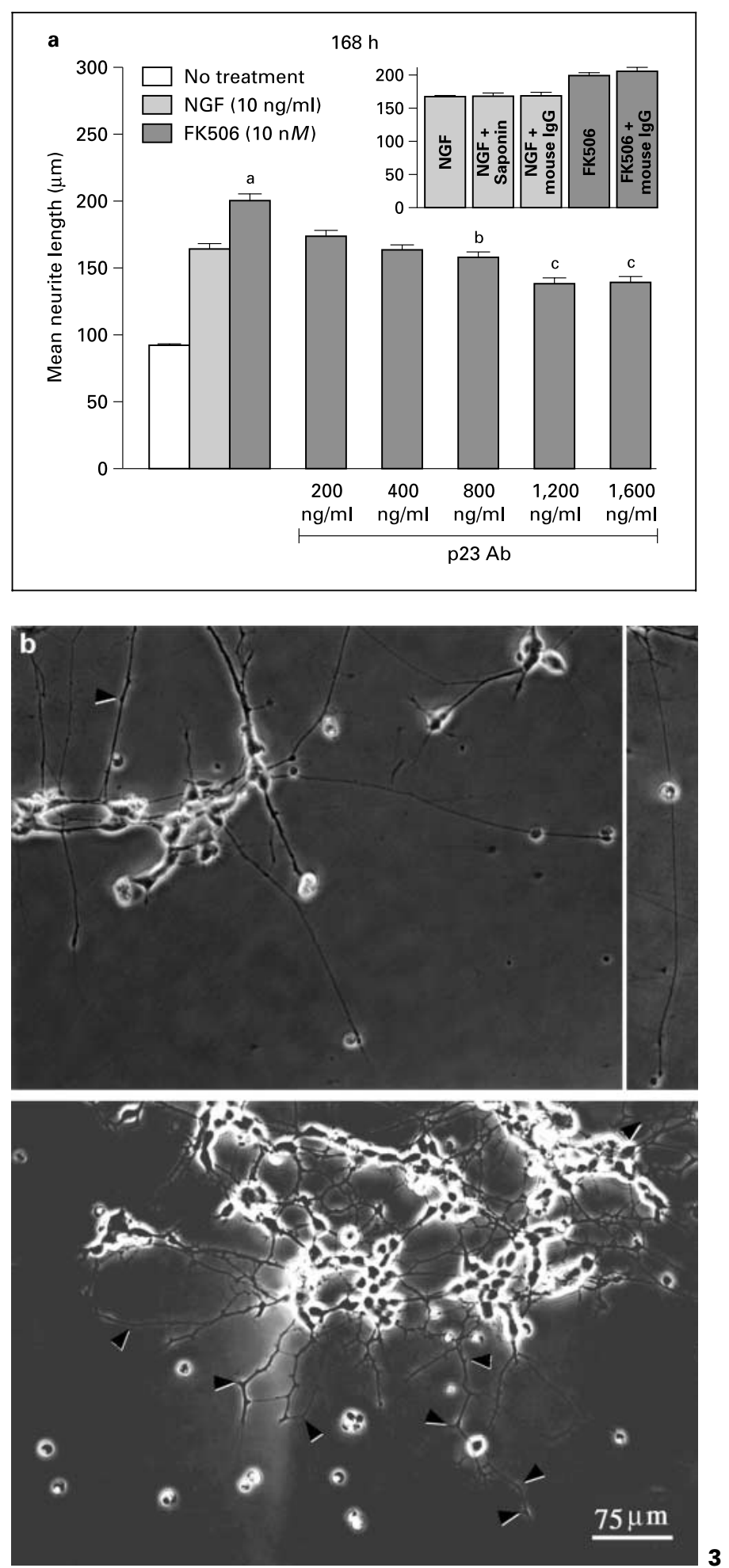
Fig. 4. A p23 antibody (JJ3) inhibits the ability of FK506 to increase ERK phosphorylation (activation). a Representative Western blots showing phosphorylated ERK1 and ERK2 (p-ERK1 and p-ERK2) and total ERK levels at $24 \mathrm{~h}$ after no treatment or treatment with NGF + FK506, or NGF + FK506 and the p23 antibody (Ab) at $800 \mathrm{ng} / \mathrm{ml}$ (left). FK506 $(10 \mathrm{n} M)$, in the absence of serum, increases phosphorylated ERK levels compared with NGF alone, which is prevented by the p 23 antibody. As a control (right), the p23 antibody $(800 \mathrm{ng} / \mathrm{ml})$ does not inhibit NGF-induced p-ERK1 and p-ERK2 (compared with NGF only). Equal amounts of protein $(20 \mu \mathrm{g})$ were applied to each lane. b Mean values (averaged from three experiments) showing relative increase in signal intensity for the bands at $12 \mathrm{~h}$, expressed as a percentage of corresponding mean NGF values. Signal intensity was detected using a GS-363 phosphorimager and Molecular Analysis software (see Materials and Methods). t-ERK $=$ Total ERK. ${ }^{*} \mathrm{p}<$ 0.05 , compared with other treatment groups.

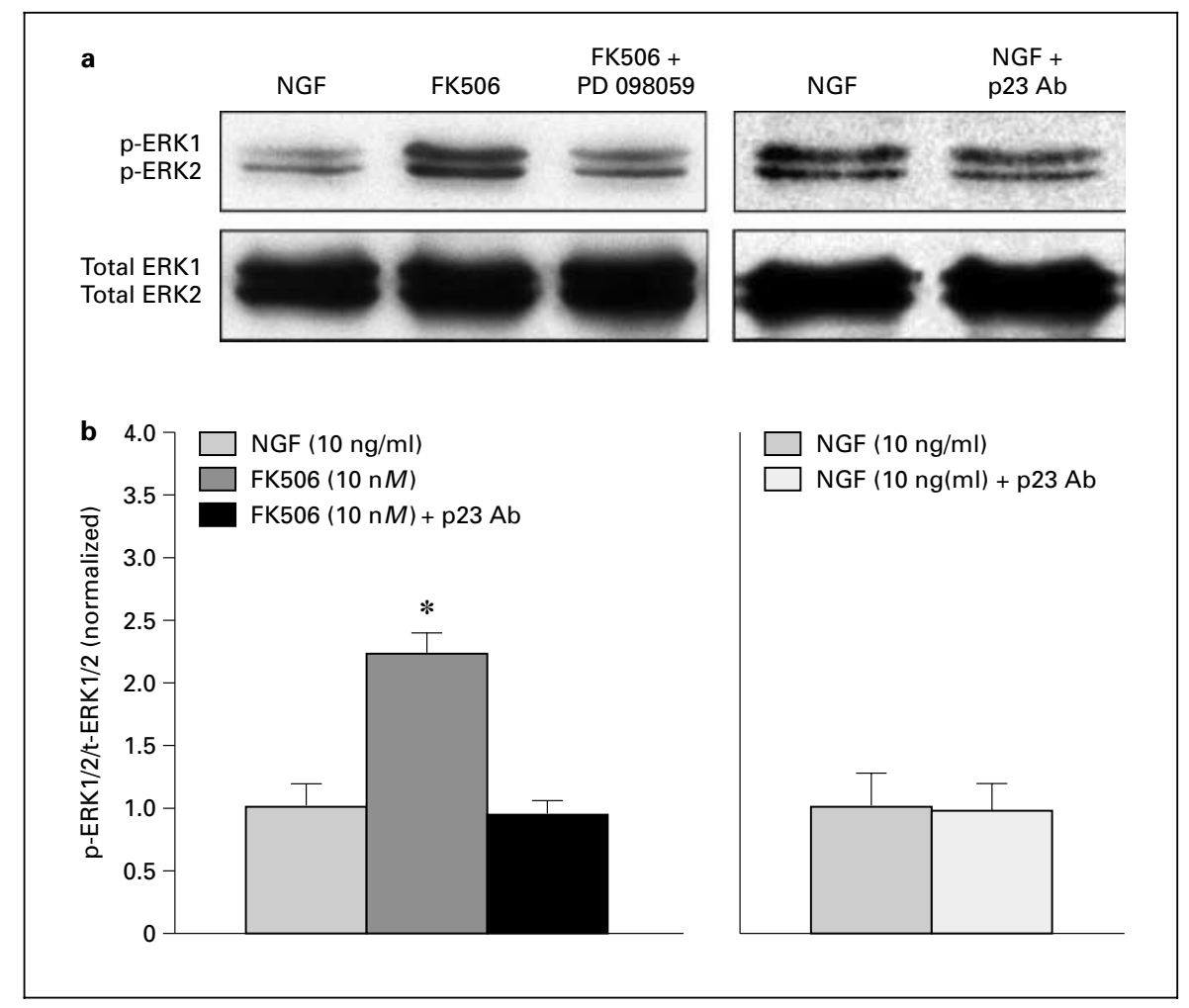

FK506), or Hsp-90 binders (geldanamycin, radicicol) is mediated by a 'gain-of-function' (involving ERK activation) following dissociation of the steroid receptor complex (namely, dissociation of p23 from Hsp-90). Thus, we asked whether an antibody to p23 would prevent neurite elongation by FK506 to examine the involvement of p23.

To address this issue in human SH-SY5Y cells, we used an IgG1 antibody (JJ3) to recombinant human p23 (Affinity BioReagents, Inc.). The SH-SY5Y cells were permeabilized with saponin $(15 \mu \mathrm{g} / \mathrm{ml}$, for $10 \mathrm{~min})$ to get the antibody into the cells; saponin alone had no effect on neurite elongation (fig. 3a, inset; see also Gold et al. [23]). We found that the p23 antibody (JJ3) markedly reduced neurite elongation by FK506 at $96 \mathrm{~h}$ (data not shown) and $168 \mathrm{~h}$ (fig. 3a) in a concentration-dependent fashion. By $168 \mathrm{~h}$, neurite elongation activity of the drug was completely prevented (i.e., reduced to NGF levels) by JJ3 at $800 \mathrm{ng} / \mathrm{ml}$ and was reduced below NGF levels at a higher $(1,200 \mathrm{ng} / \mathrm{ml})$ concentration of the p23 antibody (fig. 3a); no further reduction was observed using the antibody at a concentration of $1,600 \mathrm{ng} / \mathrm{ml}$ (fig. 3a). As a control, a mouse IgG antibody did not inhibit neurite elongation by NGF or FK506 (fig. 3a, inset). In addition, the JJ3 anti- body did not decrease the activity of NGF (data not shown). Interestingly, at $168 \mathrm{~h}$, the neurites treated with the antibody appeared jagged and more beaded (fig. 3b), suggesting rapid retraction of the processes and, perhaps, a blockade in fast axonal transport. It should be noted that overall neurite lengths were longer, and the effect of FK506 (relative to NGF) less, in this experiment compared with the ERK study (fig. 2). This difference can be attributed to the greater spontaneous outgrowth (compare 'no treatment' groups in fig. 2, 3b) in this batch of cells.

\section{Increased ERK1/2 Phosphorylation by FK506 Is Inhibited by p23 Antibody}

Since the p23 antibody prevented the neurite elongation activity of FK506, we next explored whether there is a link between p23 and ERK activation. We found that the $\mathrm{JJ} 3$ antibody at $800 \mathrm{ng} / \mathrm{ml}$ (i.e., the concentration that completely inhibited the neurite outgrowth activity of FK506; see fig. 3a) correspondingly completely inhibited the FK506-induced increase in ERK phosphorylation at 12 (not shown) and $24 \mathrm{~h}$ (fig. 4a, b, left). As a control, the p23 antibody did not inhibit NGF-induced phosphorylated ERK expression demonstrating its selectivity for FK506-mediated activity (fig. 4a, b, right). 


\section{Discussion}

The mechanism by which FK506 (neuroimmunophilin ligands) increases neurite elongation/nerve regeneration is unclear. Our previous studies have implicated the involvement of steroid receptor chaperone proteins via the immunophilin FKBP-52 [17, 20, 23]. The present study supports and extends this model by further revealing that neurite elongation by FK506 is dependent on both ERK activation (phosphorylation) and p23, but calcineurin independent. Furthermore, our findings indicate a link between p23 and ERK activation.

This is the first demonstration that ERK is involved in producing neurite elongation by FK506. ERK activation is important for neurite outgrowth induced by neurotrophic factors, including NGF $[2,3,55,57,59$; for a review, see ref. 33] and neurotrophin-3 [1]. Studies of functional involvement of the ERK pathway that rely on the PD 098059 compound need to be interpreted with caution as many studies [see, for example, ref. 4, 30, 34] are based on the use at high (30-75 $\mu M)$ concentrations that are not selective for MEK [Ed Hall, Pfizer Global Development, pers. commun.]. Thus, the ability of a relatively low $(10 \mu M)$ concentration of PD 098059, which is selective for MEK, to inhibit the activity of FK506 definitively demonstrates the involvement of ERK in the action of FK506. Furthermore, an increase in ERK activation could explain the protective action of FK506 from apoptosis induced by serum withdrawal in SH-SY5Y cells [38] and may play a role in its calcineurin-independent neuroprotective effect $[28,46]$.

While the neurotrophic activity of FK506 is clearly dependent on ERK activation, the direct upstream activator of ERK in this pathway is unknown. Hsp-90 (which binds p23) has recently been shown to directly activate Ras and MEK [40, 45]. In addition, the present study indicates that $\mathrm{p} 23$ also activates ERK via a FK506-dependent, but NGF-independent, pathway. One possible explanation is that release of p23 from Hsp-90 allows Hsp90 activation of ERK and that the p23 antibody prevents its release from Hsp-90, thereby preventing ERK activation.

Alternatively, p23 may directly activate ERK after dissociation from Hsp-90 independently of Hsp-90. To explore this issue further, we are currently examining whether the Hsp-90 binders (i.e., geldanamycin and radicicol), which release p23 from Hsp-90 [41], also increase ERK phosphorylation and whether this is prevented by Hsp-90 and/or p23 antibodies. It will also be important to directly study the physiological consequences resulting from overexpressing p23 (to test whether it increases neurite elongation and ERK activation) or expressing a dominant-negative form of $\mathrm{p} 23$ (to test whether it inhibits neurite elongation by FK506). The ultimate downstream mediators of increased neurite elongation are unknown but may include altered gene expression (e.g. c-jun, GAP-43), regulation of the dynamics of cytoskeletal elements and insertion of new membrane into the growth cone [17, 20, $23,26]$. The ability of relatively high concentrations of the p23 antibody to inhibit neurite elongation below NGF levels is reminiscent of our previous finding using the FKBP-52 antibody [23] and suggests cross-talk with the known ability of NGF to activate the ERK pathway [17, $20,26]$.

Finally, the present results provide the first demonstration of a physiological role for p23. To date, only two molecular functions are known for p23. First, it is essential for maintaining, via its binding to Hsp-90, the steroid binding domain of the mature steroid receptor complex in a conformation that has high affinity for the ligand $[8,9$, 11]. Second, a very recent paper [12] demonstrates that p23 can block transcriptional activation of steroid hormone response elements. Our findings reveal a previously unknown function of p23 in activating ERK and regulating neurite elongation. Given its ubiquitous presence in nonneuronal cells with steroid receptors, it is likely that p23 functions as a universal regulator in cell growth.

Regardless of the underlying mechanism involved, the present study strongly implicates p 23 as a novel target for the development of compounds that increase neurite elongation. Compounds that increase $\mathrm{p} 23$ expression or small molecules that are structurally similar to $\mathrm{p} 23$ should be developed as potential drug candidates for nerve regeneration.

\section{Acknowledgements}

We thank Brandon Bogardus and Sandra A. Gold for technical assistance, and Dan Austin for preparation of the figures. 


\section{References}

1 Aletsee C, Beros A, Mullen L, Palacios S, Pak K, Dazert S, Ryan AF: Ras/MEK but not p38 signaling mediates NT-3-induced neurite extension from spiral ganglion neurons. J Assoc Res Otolaryngol 2001;2:377-387.

2 Averill S, Delcroix JD, Michael GJ, Tomlinson DR, Fernyhough P, Priestley JV: Nerve growth factor modulates the activation status and fast axonal transport of ERK 1/2 in adult nociceptive neurones. Mol Cell Neurosci 2001;18:183196.

3 Boglári G, Szeberényi J: Nerve growth factor in combination with second messenger analogues causes neuronal differentiation of $\mathrm{PC} 12$ cells expressing a dominant inhibitory Ras protein without inducing activation of extracellular signal-regulated kinases. Eur J Neurosci 2001;14: 1445-1454.

4 Bonni A, Brunet A, West AE, Datta SR, Takasu MA, Greenberg ME: Cell survival promoted by the ras-MAPK signaling pathway by transcription-dependent and -independent mechanisms. Science 1999;286:1358-1362.

5 Chen JK, Capdevila J, Harris RC: Overexpression of C-terminal Src kinase blocks 14,15epoxyeicosatrienoic acid-induced tyrosine phosphorylation and mitogenesis. J Biol Chem 2000;275:13789-13792.

6 Chen S, Sullivan WP, Toft DO, Smith DF: Differential interactions of p23 and the TPR-containing proteins Hop, Cyp40, FKBP52 and FKBP51 with Hsp90 mutants. Cell Stress Chaperones 1998;3:118-129.

7 Costantini LC, Cole D, Chaturvedi P, Isacson $\mathrm{O}$ : Immunophilin ligands can prevent progressive dopaminergic degeneration in animal models of Parkinson's disease. Eur J Neurosci 2001;13:1085-1092.

8 Cox MB, Miller CA: The p23 co-chaperone facilitates dioxin receptor signaling in a yeast model system. Toxicol Lett 2002;129:13-21.

9 Dittmar KD, Demady DR, Stancato LF Krishna P, Pratt WB: Folding of the glucocorticoid receptor by the heat shock protein (hsp) 90-based chaperone machinery. J Biol Chem 1997;272:21213-21220.

10 Dubernard J-M, Owen E, Herzberg G, Lanzetta M, Martin X, Kapila H, Dawahra M, Hakim NS: Human hand allograft: Report on first 6 months. Lancet 1999;353:1315-1320.

11 Freeman BC, Felts SJ, Toft DO, Yamamoto KR: The p23 molecular chaperones act at a late step in intracellular receptor action to differentially affect ligand efficacies. Genes Dev 2000 14:422-434.

12 Freeman BC, Yamamoto KR: Disassembly of transcriptional regulatory complexes by molecular chaperones. Science 2002;296:22322235

13 Gold BG: FK506 and the role of immunophilins in nerve regeneration. Mol Neurobiol 97;15:285-306.

14 Gold BG: FK506 and the role of the immunophilin FKBP-52 in nerve regeneration. Drug Metab Rev 99;31:649-663.
15 Gold BG: The neurotrophic activity of the immunophilin ligands and benzoquinone ansamycins is mediated by dissociation of the FKBP-52/HSP-90/steroid receptor complex augmenting the mitogen-associated protein (MAP) kinase signaling pathway. Abstr Soc Neurosci 1999;25:1039.

16 Gold BG: Compositions and methods for promoting nerve regeneration. Patent No 5,968,921, Oct 19, 1999.

17 Gold BG: Neuroimmunophilin ligands and the role of steroid hormone chaperone proteins in nerve regeneration; in Gold $\mathrm{BG}$, Fischer G, Herdegen $\mathrm{T}$ (ed): Immunophilins in the Brain. FKBP-Ligands: Novel Strategies for the Treatment of Neurodegenerative Disorders. Barcelona, Prous Science, 2000, pp 3-22.

18 Gold BG: Neuroimmunophilin ligands: Evaluation of their therapeutic potential for the treatment of neurological disorders. Expert Opin Investig Drugs 2000;9:2331-2342.

19 Gold BG: Compositions and methods for promoting nerve regeneration. US patent No 5968921 (MAPKinase, bastidins, radicicols in nerve regeneration). PCT US18539 (WO 0103692 A1), 2001.

20 Gold BG: FKB506/Hsp-90 steroid receptor chaperones and ERK signaling in the regulation of nerve regeneration. J Rehabil Res Dev 2001;38:S9-S10.

21 Gold BG, Bogardus B: The immunophilin FKBP-52, a component of mature steroid receptor complexes, mediates the neurotrophic action of FK506. J Neuropathol Exp Neurol 1999;58:545.

22 Gold BG, Bogardus B: The neurotrophic action of FK506 is mediated by the immunophilin FKBP-52, a component of mature steroid receptor complexes. J Peripher Nerv Syst 1999;4: 183.

23 Gold BG, Densmore V, Shou W, Matzuk MM, Gordon HS: Immunophilin FK506-binding protein 52 (not FK506-binding protein 12) mediates the neurotrophic action of FK506. J Pharmacol Exp Ther 1999;289:1202-1210.

24 Gold BG, Katoh K, Storm-Dickerson T: The immunosuppressant FK506 increases the rate of axonal regeneration in rat sciatic nerve. $\mathrm{J}$ Neurosci 1995;15:7509-7516.

25 Gold BG, Storm-Dickerson T, Austin DR: The immunosuppressant FK506 increases functional recovery and nerve regeneration following peripheral nerve injury. Restor Neurol Neurosci 1994;6:287-296.

26 Gold BG, Villafranca JE: Neuroimmunophilin ligands: the development of novel neuroregenerative/neuroprotective compounds. Curr Top Med Chem 2003;3:1368-1375.

27 Gold BG, Zeleny-Pooley M, Wang M-S, Chaturvedi P, Armistead DM: A nonimmunosuppressant FKBP-12 ligand increases nerve regeneration. Exp Neurol 1997;147:269-278.
8 Guo X, Dawson VL, Dawson TM: Neuroimmunophilin ligands exert neuroregeneration and neuroprotection in midbrain dopaminergic neurons. Eur J Neurosci 2001;13:16831693.

29 Hoffman AL, Makowka L, Banner B, Cai X, Cramer DV, Pascualone A, Todo S, Starzl TE: The use of FK-506 for small intestine allotransplantation: Inhibition of acute rejection and prevention of fatal graft-versus-host disease. Transplantation 1990;49:483-490.

30 Jin K, Mao XO, Zhu Y, Greenberg DA: MEK and ERK protect hypoxic cortical neurons via phosphorylation of Bad. J Neurochem 2002; 80:119-125.

31 Johnson JL, Toft DO: A novel chaperone complex for steroid receptors involving heat shock proteins, immunophilins, and p23. J Biol Chem 1994;269:24989-24993.

32 Jones JW, Gruber SA, Barker JH, Breidenbach WC: Successful hand transplantation: Oneyear follow-up. N Engl J Med 2000;343:468473

33 Kaplan DR, Miller FD: Neurotrophin signal transduction in the nervous system. Curr Opin Neurobiol 2000;10:381-391.

34 Liu J, Fukunaga K, Yamamoto H, Nishi K, Miyamoto E: Differential roles of $\mathrm{Ca}^{2+} / \mathrm{cal}-$ modulin-dependent protein kinase II and mitogen-activated protein kinase activation in hippocampal long-term potentiation. J Neurosci 1999; 19:8292-8299.

35 Liu JL, Blakesley VA, Gutkind JS, LeRoith D: The constitutively active mutant Galpha13 transforms mouse fibroblast cells deficient in insulin-like growth factor-I receptor. J Biol Chem 1997;272:29438-29441.

36 Lyons WE, George EB, Dawson TM, Steiner JP, Snyder SH: Immunosuppressant FK506 promotes neurite outgrowth in cultures of PC1 2 cells and sensory ganglia. Proc Natl Acad Sci USA 1994;91:3191-3195.

37 Mackinnon SE, Doolabh VB, Novak CB, Trulock EP: Clinical outcome following nerve allograft transplantation. Plast Reconstr Surg 2001;107:1419-1429.

38 Macleod MR, Allsopp TE, McLuckie J, Kelly JS: Serum withdrawal causes apoptosis in SHSY 5Y cells. Brain Res 2001;889:308-315.

39 Perdew GH, Whitelaw ML: Evidence that the 90-kDa heat shock protein (HSP90) exists in cytosol in heteromeric complexes containing HSP70 and three other proteins with $\mathrm{M}_{\mathrm{r}}$ of 63,000, 56,000, and 50,000. J Biol Chem 1991; 266:6708-6713.

40 Pratt WB, Toft DO: Steroid receptor interactions with heat shock protein and immunophilin chaperones. Endocr Rev 1997;18:306-360.

41 Raaka BM, Finnerty M, Sun E, Samuels HH: Effects of molybdate on steroid receptors in intact $\mathrm{GH}_{1}$ cells. J Biol Chem 1985;260: 14009-14015.

42 Sánchez ER: Hsp56: A novel heat shock protein associated with untransformed steroid receptor complexes. J Biol Chem 1990;265: 22067-22070. 
43 Sánchez ER, Ning Y-M: Immunophilins, heat shock protein, and glucocorticoid receptor actions in vivo. Methods Enzymol 1996;9:188200.

44 Sano M, Yoshida M, Fukui S, Kitajima S: Radicicol potentiates neurotrophin-mediated neurite outgrowth and survival of cultured sensory neurons from chick embryo. J Neurochem 1999;72:2256-2263.

45 Setalo G Jr, Singh M, Guan X, Toran-Allerand CD: Estradiol-induced phosphorylation of ERK $1 / 2$ in explants of the mouse cerebral cortex: The roles of heat shock protein 90 (Hsp90) and MEK2. J Neurobiol 2002;50:1-12.

46 Sezen SF, Hoke A, Burnett AL, Snyder SH: Immunophilin ligand FK506 is neuroprotective for penile innervation. Nat Med 2001;7 1073-1074.

47 Silverstein AM, Galigniana MD, Radanyi C, Renoir JM, Pratt WB: Different regions of the immunophilin FKBP52 determine its association with the glucocorticoid receptor, hsp90, and cytoplasmic dynein. J Biol Chem 1999; 274:36980-36986.

48 Singh M, Sétáló Jr G, Guan X, Warren M, Toran-Allerand CD: Estrogen-induced activation of mitogen-activated protein kinase in cerebral cortical explants: Convergence of estrogen and neurotrophin signaling pathways. J Neurosci 1999;19:1179-1188.

49 Snyder SH, Lai MM, Burnett PE: Immunophilins in the nervous system. Neuron 1998;21: 283-294.
50 Starzl TE, Makowka L, Todo S: FK-506:A potential breakthrough in immunosuppression. Transplant Proc 1987;19:S3-S104.

51 Starzl TE, Todo S, Fung J, Demetris AJ, Venkataramman R, Jain A: FK-506 for liver, kidney, and pancreas transplantation. Lancet 1989;ii:1000-1004.

52 Steiner JP, Connolly MA, Valentine HL, Hamilton GS, Dawson TM, Hester L, Snyder SH: Neurotrophic actions of nonimmunosuppressive analogues of immunosuppressive drugs FK506, rapamycin and cyclosporin A. Nat Med 1997;3:421-428.

53 Steiner JP, Hamilton GS, Ross DT, Valentine HL, Guo H, Connolly MA, Liang S, Ramsey C, Li J, Huang W, Howorth P, Soni R, Fuller M, Sauer H, Nowotnik AC, Suzdak PD: Neurotrophic immunophilin ligands stimulate structural and functional recovery in neurodegenerative animal models. Proc Natl Acad Sci USA 1997;94:2019-2024.

54 Tai P-KK, Albers MW, Chang H, Faber LE, Schreiber SL: Association of a 59-kilodalton immunophilin with the glucocorticoid receptor complex. Science 1992;256:1315-1318.

55 Tsuji M, Inanami O, Kuwabara M: Induction of neurite outgrowth in PC12 cells by $\alpha$-phenyl$\mathrm{N}$-tert-butylnitron through activation of protein kinase $\mathrm{C}$ and the ras-extracellular signalregluated kinase pathway. J Biol Chem 2001; 276:32779-32785.

56 Villalonga P, Lopez-Alcala C, Bosch M, Chiloeches A, Rocamora N, Gil J, Marais R, Marshall CJ, Bachs O, Agell N: Calmodulin binds to K-Ras, but not to H- or N-Ras, and modulates its downstream signaling. Mol Cell Biol 2001;21:7345-7354.
57 Volonte C, Angelastro JM, Greene LA: Association of protein kinases ERK1 and ERK2 with p75 nerve growth factor receptors. J Biol Chem 1993;268:21410-21415.

58 Wang MS, Zeleny-Pooley M, Gold BG: Comparative dose-dependence study of FK506 and cyclosporin A on the rate of axonal regeneration in rat sciatic nerve. J Pharmacol Exp Ther 1997;282:1084-1093.

59 York RD, Yao H, Dillon T, Ellig CL, Eckert SP, McCleskey EW, Stork PJS: Rap1 mediates sustained MAP kinase activation induced by nerve growth factor. Nature 1998;392:622626.

\section{Note added in proof}

A recent publication by Price, Yamaji and Matsuoka [Br J Pharmacol 2003;140: 825-829] reports similar, albeit not independent, findings since the concept and protocols (including the 48-hour delayed treatment with the MEK inhibitor) were developed by me prior to when Dr. Yamaji was a visiting scientist in my laboratory (B.G.G.). 